\title{
Field Performance of Differentially Deteriorated Seed Lots of Maize (Zea mays) under Different Irrigation Treatments
}

\author{
Kazem GHASSEMI-GOLEZANI*, Bahareh DALIL, \\ Mohammad MOGHADDAM, Yaeghoob RAEY \\ University of Tabriz, Faculty of Agriculture, Department of Agronomy and Plant Breeding, \\ Tabriz,Iran;golezani@gmail.com (*corresponding author)
}

\begin{abstract}
A sub-sample of maize (cv. 'KSC301') seeds was kept as control or vigorous seed lot and two other sub-samples with about 16\% moisture content were artificially deteriorated at $40^{\circ} \mathrm{C}$ for 16 and 18 days. The three seed lots had seed viabilities of $99 \%\left(\mathrm{~V}_{1}\right), 91 \%\left(\mathrm{~V}_{2}\right)$ and $79 \%\left(\mathrm{~V}_{3}\right)$. Laboratory tests were carried out as $\mathrm{CR}$ design with four replicates. However, the field experiment was conducted as factorial based on RCB design with three replicates to investigate the performance of differentially deteriorated seed lots under four irrigation treatments (irrigation after 70, 90, 110 and $130 \mathrm{~mm}$ evaporation from class A pan). Germination and emergence times significantly increased with increasing seed deterioration, but mean viability percentage, seedling dry weight, seedling emergence and protein and grain yields decreased as seed deterioration increased. Even plants from less deteriorated seed lot $\left(\mathrm{V}_{2}\right)$ with acceptable germination (91\%) showed $25.1 \%$ reduction in grain yield per unit area. The superiority of $\mathrm{V}_{1}$ to $\mathrm{V}_{2}$ seeds of maize increased as water limitation increased. Protein yield was also decreased as a result of seed deterioration. Seedling dry weight highly correlated with the field emergence and grain and protein yields. Thus, it is necessary to produce and cultivate high vigor seeds of maize, in order to ensure satisfactory yield achievement, particularly under adverse environmental conditions.
\end{abstract}

Keywords: grain yield, maize, seed deterioration, seedling emergence, seed vigor

\section{Introduction}

Maize with a remarkable productive potential among the cereals, is the third important grain crop after wheat and rice and accounts for $4.8 \%$ of the total cropped area and $3.5 \%$ of the value of the agricultural output (Anonymous, 2004). Maize had its origin in a semi-arid area but water deficit can limit the production of this crop (Ghassemi-Golezani et al., 1997).

Water stress is a major abiotic stress that severely affects food production worldwide. When the full crop requirements are not met, water deficit in the plant can develop to a point where crop growth and yield are affected (Baigorri et al., 1999; Costa-Franca et al., 2000). Different strategies can be adopted to improve crop performance under drought stress, one of which may be the cultivation of high vigor seeds. Seed quality reflects potential seed germination, field emergence and seedling establishment under different environmental conditions (Sun et al., 2007).

Many reports (Demir and Ellis, 1992; Ghassemi-Golezani and Mazloomi-Oskooyi, 2008; Ghassemi-Golezani and Hossinzadeh-Mahootchy, 2009) suggest that the maximum seed quality is achieved at or slightly after mass maturity (end of seed filling period). Then, seeds begin to deteriorate on the mother plant (Ghassemi-Golezani and Mazloomi-Oskooyi, 2008; Ghassemi-Golezani and Hoss-
inzadeh-Mahootchy, 2009). Seed deterioration continues during storage, losing viability and vigor (Ellis and Roberts, 1981). Seed deterioration is not possible to stop totally but it can be minimize the rate of deterioration. When deterioration is advanced, germination rate and uniformity and tolerance to environmental stresses and consequently seedling emergence decreased (Khan et al., 2003). High and rapid germination, ensure good stand establishment which may result in higher yields (Ghassemi-Golezani et al., 2010). So fast and uniform germination are as important for superior crop production as is total germination, while slow, non-uniform and unreliable germination and emergence due to low quality seeds (Matthews, 1980) leads to problems for successful crop production.

Seed quality may influence crop yield through both indirect and direct effects. The indirect effects include those on percentage emergence which influence yield by altering plant population density and spatial arrangement. Direct effects are those on emergence rate which influence seedling vigor and uniformity (Ghassemi-Golezani, 1992). Some reports have shown that low seed quality due to deterioration causes poor stand establishment in the field and consequently yield loss of wheat (Ganguli and SenMandi, 1990), barley (Abdalla and Roberts, 1969) and oilseed rape (Ghassemi-Golezani et al., 2010). However, the effects of seed deterioration on field performance of 
maize are not well documented. Thus, this research was carried out to evaluate the effects of seed deterioration on field establishment and grain and protein yields of maize under full and limited irrigation conditions.

\section{Materials and methods}

Seeds of maize (cv. 'KSC301') were obtained from Agricultural Research Center of Karaj, Iran. These seeds were divided into three sub-samples. A sub-sample was kept as control or high vigor seed lot $\left(V_{1}\right)$. The two other subsamples with about $16 \%$ moisture content were artificially deteriorated at $40^{\circ} \mathrm{C}$ for 16 and 18 days $\left(V_{2}\right.$ and $V_{3}$, respectively). As a result, the three seed lots had seed viabilities of $99 \%\left(\mathrm{~V}_{1}\right), 91 \%\left(\mathrm{~V}_{2}\right)$ and $79 \%\left(\mathrm{~V}_{3}\right)$.

Laboratory tests were carried out at the Seed Technology Laboratory of University of Tabriz, Iran, using randomized complete design (CRD). Four replicates of 25 seeds were germinated between double layered rolled germination papers. The rolled papers with seeds were put into plastic bags to avoid moisture loss. Seeds were allowed to germinate at $15 \pm 1^{\circ} \mathrm{C}$. Germination was considered to have occurred when the radicles were $2 \mathrm{~mm}$ long. Germinated seeds were recorded every 24 hours for 10 days. Mean germination time (MGT) was calculated according to Ellis and Roberts (1980):

\section{$\mathrm{MGT}=\sum(\mathrm{D} \times \mathrm{n}) / \sum \mathrm{n}$}

where $\mathrm{n}$ is the number of seeds germinated on day $\mathrm{D}$ and $\mathrm{D}$ is the number of days counted from the beginning of the test. At the end of germination test, radicles and shoots of normal seedlings were cut from the cotyledons and then dried in an oven at $75 \pm 2^{\circ} \mathrm{C}$ for 24 hours. The dried radicles and shoots were weighed to the nearest milligram and the mean seedling dry weight was determined.
Field experiment was conducted in 2009 at the Research Farm of the Faculty of Agriculture, University of Tabriz (latitude $38.05^{\circ} \mathrm{N}$, longitude $46.17^{\circ} \mathrm{E}$, altitude $1360 \mathrm{~m}$ above sea level). The experimental design for the field experiment was factorial, based on randomized complete block design with three replicates. Factors were three seed lots $\left(V_{1}, V_{2}\right.$ and $\left.V_{3}\right)$ and four irrigation regimes $\left(\mathrm{I}_{1}, \mathrm{I}_{2}, \mathrm{I}_{3}, \mathrm{I}_{4}\right.$ for irrigation after $70,90,110$ and $130 \mathrm{~mm}$ evaporation from class A pan, respectively). Seeds were treated with Benomyl (fungicide) at a rate of $2 \mathrm{~g} \mathrm{~kg}^{-1}$ before sowing. The seeds were then sown on 16 May 2009 in a sandy-loam soil $(\mathrm{PH}=8.1)$ at a depth of about $4 \mathrm{~cm}$ with a density of 10 seeds $\mathrm{m}^{-2}$. Seedling emergence in each plot was counted in daily intervals until no more emergences were observed. Subsequently, mean emergence time and percentage of seedling emergence were calculated. At maturity, plants in $1 \mathrm{~m}^{2}$ of each plot were harvested and grain yield per unit area was determined. Percentages of protein for each sample were measured, using a seed analyzer (model: Zeltex ZX-50) and then Protein yield per unit area was calculated as:

Protein yield per unit area $=$ grain yield per unit area $\times$ protein percentage

Analysis of variance of the data appropriate to the experimental design was carried out, using MSTATC software. Means of the traits were compared by Duncan multiple range test at $\mathrm{p} \leq 0.05$.

\section{Results}

Seed deterioration had significant effects on viability percentage, mean germination time, seedling dry weight, percentage of seedling emergence, emergence time $(\mathrm{p} \leq 0.01)$ and protein and grain yields $(\mathrm{p} \leq 0.05)$. In con-

Tab. 1. Comparison of means for different traits affected by seed deterioration

\begin{tabular}{ccccccccc}
\hline $\begin{array}{c}\text { Seeds } \\
\text { lot }\end{array}$ & $\begin{array}{c}\text { Viability } \\
(\%)\end{array}$ & $\begin{array}{c}\text { Germination } \\
\text { time }(\text { day })\end{array}$ & $\begin{array}{c}\text { Seedling dry } \\
\text { weight }(\mathrm{g})\end{array}$ & $\begin{array}{c}\text { Seedling } \\
\text { emergence }(\%)\end{array}$ & $\begin{array}{c}\text { Emergence } \\
\text { time }(\text { day })\end{array}$ & $\begin{array}{c}\text { Grain yield } \\
\text { per plant }(\mathrm{g})\end{array}$ & $\begin{array}{c}\text { Protein } \\
\text { yield }\left(\mathrm{g} \mathrm{m}^{-2}\right)\end{array}$ & $\begin{array}{c}\text { Grain yield } \\
\left.(\mathrm{g} \mathrm{m})^{-2}\right)\end{array}$ \\
\hline $\mathrm{V}_{1}$ & $99.00 \mathrm{a}$ & $3.30 \mathrm{c}$ & $1.01 \mathrm{a}$ & $83.05 \mathrm{a}$ & $9.18 \mathrm{c}$ & $39.03 \mathrm{a}$ & $37.07 \mathrm{a}$ & $312.0 \mathrm{a}$ \\
$\mathrm{V}_{2}$ & $91.00 \mathrm{~b}$ & $5.51 \mathrm{~b}$ & $0.29 \mathrm{~b}$ & $44.87 \mathrm{~b}$ & $14.02 \mathrm{~b}$ & $57.08 \mathrm{a}$ & $26.82 \mathrm{ab}$ & $233.7 \mathrm{ab}$ \\
$\mathrm{V}_{3}$ & $79.00 \mathrm{c}$ & $6.26 \mathrm{a}$ & $0.14 \mathrm{c}$ & $35.55 \mathrm{c}$ & $15.72 \mathrm{a}$ & $56.76 \mathrm{a}$ & $20.68 \mathrm{~b}$ & $184.9 \mathrm{~b}$ \\
\hline
\end{tabular}

Different letters at each column for each treatment indicate significant difference at $\mathrm{p} \leq 0.05$

Tab. 2. Correlation coefficients of various laboratory and field traits of maize

\begin{tabular}{|c|c|c|c|c|c|c|c|c|}
\hline Traits & 1 & 2 & 3 & 4 & 5 & 6 & 7 & 8 \\
\hline 1-Viability (\%) & 1 & & & & & & & \\
\hline 2-Germination time & -0.786 & 1 & & & & & & \\
\hline 3-Seedling dry weight & $0.758^{*}$ & -0.986 & 1 & & & & & \\
\hline 4-Seedling emergence (\%) & $0.786^{*}$ & $-0.982^{* *}$ & $0.997^{* *}$ & 1 & & & & \\
\hline 5-Emergence time & $-0.839^{* *}$ & $0.975^{* *}$ & $-0.987^{* *}$ & $-0.990^{* *}$ & 1 & & & \\
\hline 6-Grain yield per plant (g) & -0.221 & 0.112 & -0.078 & -0.102 & 0.071 & 1 & & \\
\hline 7-Protein yield $\left(\mathrm{g} / \mathrm{m}^{2}\right)$ & $0.667^{*}$ & $-0.812^{* *}$ & $0.841^{* *}$ & $0.842^{* *}$ & $-0.861^{*}$ & -0.264 & 1 & \\
\hline 8-Grain yield ( $\mathrm{g} / \mathrm{m} 2)$ & $0.711^{*}$ & $-0.806^{* *}$ & $0.839^{* *}$ & $0.848^{* *}$ & $-0.873^{* *}$ & -0.217 & $0.989^{* *}$ & 1 \\
\hline
\end{tabular}

${ }^{*},{ }^{* *}$ : Statistically significant at $\mathrm{p} \leq 0.05$ and $\mathrm{p} \leq 0.01$, respectively 
162
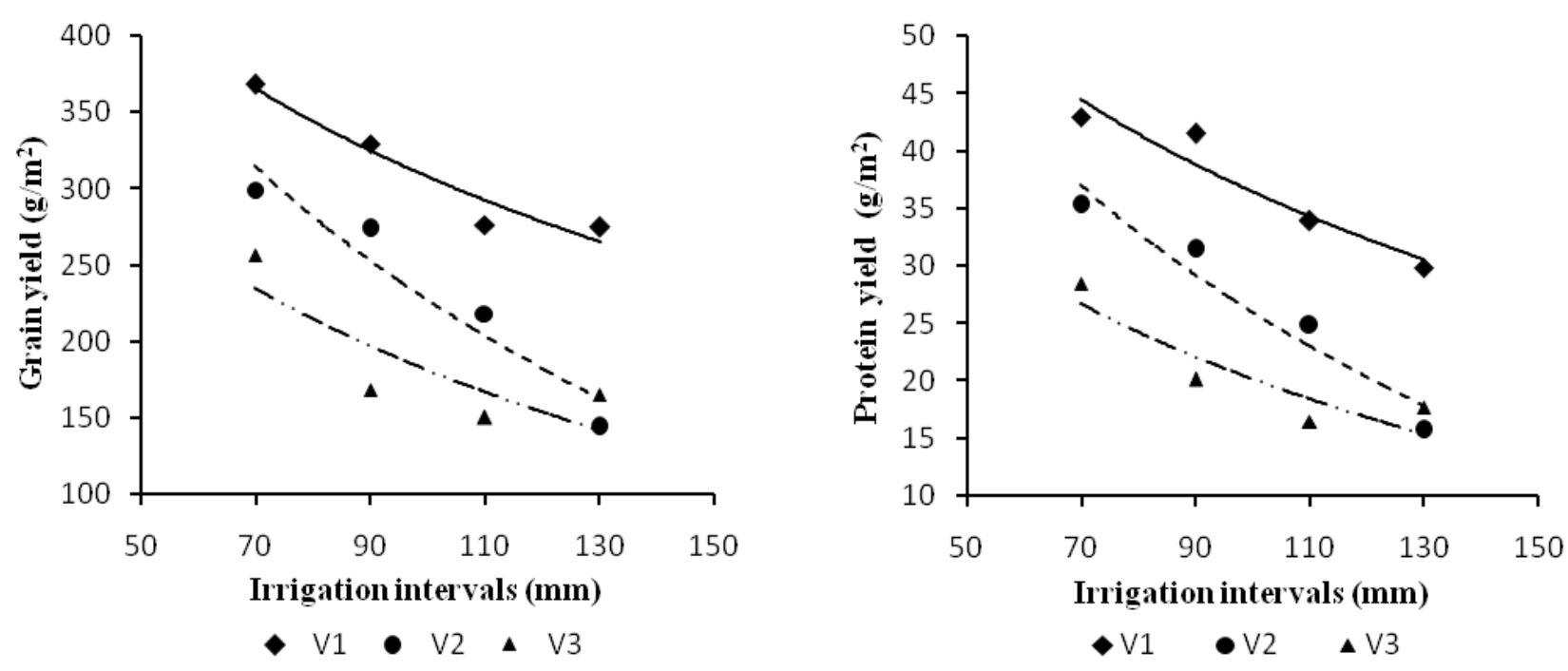

Fig. 1. Changes in grain and protein yields per unit area for plants from different seed lots of maize (cv. 'KSC301') under various irrigation intervals. $\mathrm{V}_{1}, \mathrm{~V}_{2}$ and $\mathrm{V}_{3}$ : Control and deteriorated seed lots with $99 \%, 91 \%$ and $79 \%$ viability, respectively

trast, grain yield per plant $(\mathrm{g})$ and protein percentage were not significantly affected by seed deterioration $(p \leq 0.05)$.

Viability percentage, seedling dry weight, seedling emergence, protein yield and grain yield decreased with increasing seed deterioration and decreasing seed vigor, but mean germination and emergence times increased as seed vigor decreased. Grain yield per plant from high vigor seed lot was slightly, but not significantly $(\mathrm{P} \leq 0.05)$, lower than that of low vigor seed lots (Tab. 1).

Grain and protein yields of plants from all seed lots decreased with increasing irrigation intervals, but this reduction for plants from $\mathrm{V}_{2}$ seeds was more than that for plants from the other seed lots. Plants from high vigor seed lot $\left(V_{1}\right)$ had the highest grain and protein yields per unit area under all irrigation treatments, followed by the plants from $\mathrm{V}_{2}$ and $\mathrm{V}_{3}$ seed lots, respectively (Fig. 1).

Viability percentage, seedling dry weight, emergence percentage, protein yield and grain yield had positive and significant correlations with each other. However, these traits negatively correlated with germination and emergence times. Among laboratory traits, seedling dry weight had the highest correlation with protein and grain yields per unit area. The relationship between grain yield per plant and any of the laboratory and field traits was not significant (Tab. 2).

\section{Discussion}

Delaying germination and seedling emergence ( Tab. 1) due to seed deterioration are the result of disruption in RNA transcription and protein synthesis (Thornton et al., 1993), membrane damage (Bewley, 1986) and solute leakage (Bewley and Black, 1994). As deterioration proceeds, seeds lose their viability and vigor leading to reductions in percentage of seedling emergence and stand establishment
(Tab. 1). Since there is a strong relationship between plant density and yield (Raey and Ghassemi-Golezani, 2009), low plant populations resulting from low vigor seeds can potentially decrease crop yield per unit area (Tekrony and Egli, 1991).

When low populations of plants from aged seeds were compared with similar populations obtained from low sowing rates of high vigor seeds, the plants from the former seeds yielded less than those from the latter (Perry, 1980). In the present research, poor stand establishment of plants from artificially deteriorated seed lots resulted in comparatively higher grain yield per plant (Tab. 1), suggesting that early emergence of seedlings from high vigour seeds was overcome by efficient use of environmental resources by individual plants from low vigour seeds. Nevertheless, the superiority in grain yield per plant was not sufficient to compensate for low and scattered plant establishment due to seed deterioration, as indicated by large reduction (up to $40.74 \%$ ) in grain yield per unit area. Similar results were reported for winter oilseed rape (Ghassemi-Golezani et al., 2010). Even plants from less deteriorated seed lot $\left(V_{2}\right)$ with acceptable germination $(91 \%)$ showed $25.1 \%$ reduction in grain yield per unit area, compared with those from high vigor seed lot $\left(V_{1}\right)$ (Tab. 1). This difference between plants from $V_{1}$ and $V_{2}$ seed lots increased with increasing irrigation intervals. In other words, the advantage of sowing high vigor seeds for improving field performance of maize increased as water supply decreased (Fig. 1). Low population of barley brought about by the interaction of low vigor seed lot and an adverse environment was also associated with a lower yield and the surviving plants were not able to compensate completely for the missing plants (Perry, 1980).

Since protein percentage was not significantly affected by seed vigor $(\mathrm{p} \leq 0.05)$, decreasing protein yield per unit 
area for plants from differentially deteriorated seed lots can be attributed to considerable reduction in grain yield per unit area (Tab. 1). Similarly, total protein per unit area in pearl millet reduced primarily due to lower grain yield under the limited water availability (Mahalakshmi et al., 2006). Changes in protein yield of plants from various seed lots of maize under different irrigation treatments were also similar to those of grain yield per unit area (Fig. $1)$.

Significant correlations of seed viability, mean germination time and seedling dry weight with each other and with field traits such as seedling emergence and grain and protein yields per unit area (Tab. 2) indicated that each of the seed quality parameters enable to estimate the potential field performance of different maize seed lots. However, the highest correlation of seedling dry weight with the same field traits (Tab. 2) clearly suggests that the seedling growth test is the best quality test for maize seed lots.

It can be concluded that sowing high vigor seeds enhances crop yield through improving seedling establishment, particularly under adverse environmental conditions. Therefore, It is well justified to produce high vigor seeds of maize and to provide proper storage conditions in order to ensure optimum stand establishment and satisfactory yield under a wide range of field conditions. Seedling growth test is the best test for evaluating seed and seedling vigor of maize seed lots.

\section{Acknowledgements}

The authors sincerely appreciate the administrator of the University of Tabriz (Iran) for the financial support of this research.

\section{References}

Abdalla FH, Roberts EH (1969). The effect of seed storage conditions on the growth and yield of barley, broad beans and peas. Ann Bot 33:169-184.

Anonymous (2004). Agriculture Statistics, FAOSTAT, United Nation Organization.

Baigorri H, Antolini MC, Sanchez-DiazM (1999). Reproductive response of two morphologically different pea cultivars to drought. Europ J Agron 10:119-128.

Bewley JD (1986). Membrane changes in seeds as related to germination and perturbations resulting from deterioration in storage, 27-45 p. In: McDonald MB Nelson CJ (Eds.). Physiology of seed deterioration. Crop Science Society of America, Madison, Wisconsin.

Bewley JD, Black M (1994). Seeds: Physiology of Development and Germination. Plenum Press.

Costa-Franca MG, Thi AT, Pimental C, Pereyra RO, ZuilyFodil Y, Laffray D (2000). Differences in growth and water relations among Phaseolus vulgaris cultivars in response to induced drought stress. Environ Exp Bot 43: 227-237.

Demir I, Ellis RH (1992). Changes in seed quality during seed development and maturation in tomato. Seed Sci Res 2:8187.

Ellis RH, Roberts EH (1980). Towards a rational basis for testing seed quality, 605-635 p. In: Hebblethwaite PD (Ed.). Seed Production. Butterworths, London.

Ellis RH, Roberts EH (1981). The quantification of ageing and survival in orthodox seeds. Seed Sci Technol 9:373-409.

Ganguli S, Sen-Mandi S (1990). Some physiological differences between naturally and artificially aged wheat seeds. Seed Sci Technol 18:507-514.

Ghassemi-Golezani K (1992). Effects of seed quality on cereal yields. PhD Thesis. University of Reading, UK.

Ghassemi-Golezani K, Hossinzadeh-Mahootchy A (2009). Changes in seed vigor of faba bean (Vicia faba L.) cultivars during development and maturity. Seed Sci Technol 37:713720 .

Ghassemi-Golezani K, Khomari S, Dalil B, HosseinzadehMahootchy A, Chadordooz Jeddi A (2010). Effects of seed aging on field performance of winter oilseed rape. J Food Agri Environ 8:175-178.

Ghassemi-Golezani K, Mazloomi-Oskooyi R (2008). Effect of water supply on seed quality development in common bean (Phaseolus vulgaris). Inter J Plant Pro 2:117-124.

Ghassemi-Golezani K, Soltani A, Atashi A (1997). The effect of water limitation in the field on seed quality of maize and sorghum. Seed Sci Technol 25:321-323.

Khan MM, Iqbal MJ, Abbas M, Usman M (2003). Effect of accelerated ageing on viability, vigor and chromosomal damage in pea (Pisum sativum L.) seeds. Pak J Agri Sci 40:50-54.

Mahalakshmi V, Subramanian V, Bidinger FR, Jambunathan R (2006). Effect of water deficit on yield and protein content in pearl millet grains. J Sci Food Agri 36:1237-1242.

Matthews S (1980). Controlled deterioration: a new vigour test for crop seeds, 513-526 p. In: Hebblethwaite PD (Ed.). Seed Production. Butterworths, London.

Perry DA (1980). Deterioration of barley seed and its effects on field performance, 327-337 p. In: Hebblethwaite PD (Ed.). Seed Production. Butterworths, London.

Raey Y, Ghassemi-Golezani K (2009). Yield-density relationship for potato (Solanum tuberosum) and common bean (Phaseolus vulgaris) in intercropping. New Zealand J Crop Hort Sci 37:141-147.

Sun Q, Wang JH, Sun BQ (2007). Advances in seed vigor physiological and genetic mechanisms. Agri Sci China 6:1060-1066.

Tekrony DM, Egli DB (1991). Relationship of seed vigor to crop yield: A review. Crop Sci 31:816-822.

Thornton JM, Collins ARS, Powell AA (1993). The effect of aerated hydration on DNA synthesis in embryos of Brassica oleracea L. Seed Sci Res 3:195-199. 